\title{
Assessment of Listeria monocytogenes in pet food
}

\author{
Lesley Maurice Bilung ${ }^{*}{ }^{\dagger}$, Victoria Ulok ${ }^{\dagger}$, Feven Mehari Tesfamariam ${ }^{\dagger}$ and Kasing Apun ${ }^{\dagger}$
}

\begin{abstract}
Background: Listeria monocytogenes is one of the commonly isolated foodborne pathogens which cause illness, and listeriosis is a disease caused by this pathogen in human beings. Pets that consume contaminated pet food diets can be colonized by L. monocytogenes without showing clinical signs making the pets a possible source of contamination in the household. This study aimed to detect and enumerate the presence of L. monocytogenes in pet food diets, namely cat and dog food.

Result: A total of 32 samples consisting of wet food (25\%), dry food (25\%), treats (25\%), and leftover household samples $(25 \%)$ were examined for this study. The pet food diets were sampled from pet food shops, grocery stores, and households located in Kuching and Kota Samarahan. The analysis was conducted using the most probable numberpolymerase chain reaction (MPN-PCR). According to the results obtained from MPN-PCR, none of the samples were contaminated by L. monocytogenes.
\end{abstract}

Conclusion: Being the first biosafety assessment of L. monocytogenes in pet food in Malaysia, this study can contribute to the building of a database regarding the potential contamination of pet food diets by L. monocytogenes.

Keywords: Listeria monocytogenes, Most probable number-polymerase chain reaction, Pet food

\section{Background}

Listeria monocytogenes is recorded to be one of the numerous foodborne pathogens that cause foodborne illness [13]. It is rod-shaped, non-spore forming, facultative anaerobe and gram-positive bacteria which are known to be an opportunistic intracellular pathogen. Listeriosis is a rare but a serious foodborne disease which is caused by the pathogen L. monocytogenes. When compared to other foodborne pathogens such as Salmonella, listeriosis is known to have high fatality rates (20-30\%). Even though L. monocytogenes cause a mild gastroenteritis in healthy adults, the illness can be severe in immunocompromised individuals, pregnant women, infants, and the elderly. Listeria species are tolerant to extreme conditions such as low temperature, high salt concentration, and low $\mathrm{pH}$.

\footnotetext{
*Correspondence: mblesley@unimas.my

†Lesley Maurice Bilung, Victoria Ulok, Feven Mehari Tesfamariam, and Kasing Apun contributed equally to this work

Department of Molecular Biology, Faculty of Resource Science and Technology, Universiti Malaysia Sarawak, 94300 Kota Samarahan, Sarawak, Malaysia
}

As a result, they are present in a variety of environments which include water, sewage, effluents, silage, soil, and foods [8].

Pet food is a food intended for pet consumption, and the pet food diets used in this research were foods for cats and dogs. The cat/dog food samples are commercially prepared dry food, wet food, and treats and leftover household foods. L. monocytogenes can cause infection in both cats and dogs. In some cases, these companion animals show no symptoms, but they continue to shed L. monocytogenes in their stool causing zoonotic health threat [17]. Although rare cases of listeriosis in companion animals, especially dogs and cats, have been reported, some clinical manifestations have been observed such as abortion, septicaemia with encephalomyelitis, or cutaneous form [3, 14, 20, 21, 24]. According to US Food and Drug Administration [23], several recalls of pet food diets had been made due to the fear of potential contamination by $L$. monocytogenes. The contamination of commercially prepared pet food diets by $L$. monocytogenes has been reported in many cases, especially in the USA 
$[18,23]$. This indicates that various pet food diets are susceptible to contamination by $L$. monocytogenes leading to infections that are detrimental to human beings as well as animals. Even though there have been cases of pet food recalls due to contamination by L. monocytogenes, there are very limited data regarding pet food contamination with L. monocytogenes worldwide. In Malaysia, there are no published reports available on the prevalence of L. monocytogenes or other pathogens in pet food. As a result, this study was carried out to assess the presence of $L$. monocytogenes in pet foods under the hypothesis that there is a risk of transmission of L. monocytogenes from pet food to human beings causing a health threat to susceptible individuals. The aim of this study is to determine the presence of Listeria monocytogenes in various types of cat/dog food using MPN-PCR method. This study is the first biosafety assessment of L. monocytogenes in Malaysia; as a result, the findings from this study can be used to provide a baseline data and to create awareness regarding pet food contamination in Malaysia.

\section{Methods}

\section{Sample collection}

Twenty-four dog and cat food samples were randomly purchased from seven locations in Kuching and Kota Samarahan. These samples encompassed commercially prepared dry dog/cat food, wet dog/cat food, and treat for dogs. The samples were purchased in different forms of packaging. Some of these samples were packed, i.e., they were packed in the companies they were produced, whereas some of the samples were repacked into smaller bags in their respective pet food shops. Most of the repacked pet food samples were kibbles/pellets and treats. Some were unpacked, meaning that they were displayed in the shops and were not packed. All the unpacked samples were dog treats. Eight samples were collected from households, and the foods from the households were human leftover foods that were comprised of cooked rice (sample no. 25 , sample no. 26 , and sample no. 28 ), rice with long bean (sample no. 27), ice with seafood (sample no. 30), rice with chicken meat (sample no. 31), rice with anchovy (sample no. 32), and rice with anchovy and vegetables (sample no. 32), which were fed to dogs or cats. Before the foods were given to the companion animals, some of them were kept in a sterile bag and stored in ice for transportation. The analysis was done as soon as possible upon sample receipt. For each of the samples, two replicates were used. The unpacked treats were displayed in a big box. As a result, two treats from the same box were purchased as two replicates and the whole box containing the treats was counted as one sample.

\section{Pre-enrichment}

The initial suspension $\left(10^{-1}\right.$ dilution) was prepared by mixing ten grams of the food sample with $90 \mathrm{ml}$ of buffered peptone water (BPW) in a stomacher bag. The sample was homogenized manually for $1-3 \mathrm{~min}$, and following this it was incubated for $1 \mathrm{~h}$ at $20{ }^{\circ} \mathrm{C}$. In some cases, the samples were less than $10 \mathrm{~g}$ or more than $10 \mathrm{~g}$ and could not be broken down into pieces. In this case, the samples were weighed as a whole $(S)$ and were mixed in $9 \times \mathrm{S}$ of BPW. Then, all the samples were serially diluted in the ratio 1:100 and 1:1000 with BPW [15].

\section{Enumeration by most probable number (MPN) method}

For enumeration by MPN, $1 \mathrm{ml}$ of three successive tenfold dilutions was transferred into three test tubes that contain $9 \mathrm{ml}$ of fraser (BD Difco ${ }^{\mathrm{TM}}$ ) broth. The nine tubes were then incubated for $48 \mathrm{~h}$ at $30{ }^{\circ} \mathrm{C}$. Then, the tubes were checked for turbidity [9]. The number of turbid tubes per replicate was scored against an MPN table to find the most probable number. PCR was then conducted to confirm the presence of L. monocytogenes.

\section{DNA extraction}

DNA extraction was conducted using the boiled-cell method [16]. A $500 \mu \mathrm{l}$ [9] portion of the broth was centrifuged at $10,000 \mathrm{rpm}$ for $2 \mathrm{~min}$. The pellet was then resuspended in $500 \mu \mathrm{l}$ of sterile distilled water and vortex in order to re-suspend the pellets. Then, the tubes were boiled at $100{ }^{\circ} \mathrm{C}$ for $10 \mathrm{~min}$. Following this, the tubes were allowed to cool down at $-20^{\circ} \mathrm{C}$ for $5 \mathrm{~min}$ and were centrifuged at 12,000 rpm for $5 \mathrm{~min}$. The supernatant was then collected to be used as a template solution for PCR amplification.

\section{Polymerase chain reaction (PCR)}

For PCR amplification, the nucleotide sequences of the primer specifically amplified the $730 \mathrm{bp}$ regions of the hly gene (listeriolysin $\mathrm{O}$ gene). The primers are forward 5'-CAT TAG TGG AAA GAT GGA ATG- $3^{\prime}$ and reverse 5'-GTA TCC TCC AGA GTG ATC GA-3' [1]. The amplification was performed in $25 \mu \mathrm{l}$ of reaction mixture con-

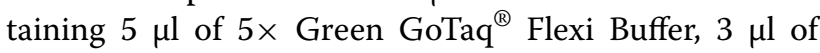
$25 \mathrm{mM} \mathrm{MgCl}$ solution, $0.5 \mu \mathrm{l}$ of $10 \mathrm{mM}$ PCR Nucleotide mix, $0.15 \mu \mathrm{l}$ of GoTaq ${ }^{\circledR}$ DNA polymerase $(5 \mathrm{U} / \mu \mathrm{l}), 0.5 \mu \mathrm{l}$ of each primer, $2 \mu \mathrm{l}$ of template DNA, (Promega Corporation, USA), and $13.35 \mu \mathrm{l}$ sterile distilled water. Following this, the reaction mixtures were heated at $95{ }^{\circ} \mathrm{C}$ for $2 \mathrm{~min}$ in the initial denaturation step followed by 30 cycles of denaturation at $95^{\circ} \mathrm{C}$ for $30 \mathrm{~s}$, annealing at $53^{\circ} \mathrm{C}$ for $1 \mathrm{~min}$, and extension at $72{ }^{\circ} \mathrm{C}$ for $2 \mathrm{~min}$. Finally, the sample mixture was heated at $72{ }^{\circ} \mathrm{C}$ for $7 \mathrm{~min}$ in the final denaturation step. 


\section{Agarose gel electrophoresis (AGE)}

For the PCR products to be visualized, $5 \mu \mathrm{l}$ of PCR product was run on $1.0 \%(\mathrm{w} / \mathrm{v})$ agarose gel using $1 \times \mathrm{TBE}$ buffer for $60 \mathrm{~min}$ at $100 \mathrm{~V}$. The gel was then stained with ethidium bromide and viewed under ultraviolet (UV) light [9].

\section{Results}

In this study, 32 samples were collected from shops and households located in Kota Samarahan and Kuching. The tubes that turned black were considered as presumptive positive. Only the tubes containing three samples turned black, indicating the presence of Listeria species. For the other twenty-nine pet food samples, none of the tubes turned black, indicating the absence of Listeria species. PCR was performed to confirm the presence or absence of Listeria monocytogenes. PCR was performed for twenty-eight samples but could not be performed for four samples due to lack of primers. However, these four samples are from the twenty-nine samples where no change of color was observed in the tubes containing the sample and Fraser broth. Table 1 shows the MPN and PCR result for all the samples. The MPN table for a three-replicate design was adapted from FDA's Bacterial Analytical Manual [25].

Sample number 25, 26 and 27 were positive for Listeria species as some of the tubes containing Fraser broth along with the samples turned black. All three samples were human leftover foods that were given to the companion animals (dogs/cats). For sample number 25.1, all the tubes with $10^{-1}$ dilution factor turned black, whereas, for sample number 25.2, only two tubes with $10^{-1}$ dilution factor turned black. For sample number 26, all the tubes for the two replicates turned black. As for sample number 27.1 , only two tubes with $10^{-3}$ dilution factor remained yellow and the other seven tubes turned black. Similarly, most of the tubes of sample number 27.2 turned black, but all the tubes with $10^{-3}$ dilution factor remained yellow. For the other twenty-nine samples, none of the tubes turned black, indicating a negative result.

Only three samples indicated a possible contamination by L. monocytogenes. Nevertheless, with the help of PCR all three samples were confirmed negative, i.e., no $L$. monocytogenes were present in the samples. Figure 1 represents the gel electrophoresis image for the identification of L. monocytogenes. As seen in Fig. 1, except for the positive control, no bands were observed for the samples. Furthermore, Table 2 shows the minimum MPN/g, median MPN/g, and maximum MPN/g of the different types of pet food diets.
Table 1 MPN and PCR result for the samples tested

\begin{tabular}{|c|c|c|c|c|c|}
\hline \multirow{2}{*}{$\begin{array}{l}\begin{array}{l}\text { Sample } \\
\text { numbers }\end{array} \\
1\end{array}$} & \multicolumn{2}{|c|}{ Types of samples } & \multirow{2}{*}{$\begin{array}{l}\text { Replicates } \\
1.1 \\
1.2\end{array}$} & \multirow{2}{*}{$\begin{array}{l}\text { MPN/g } \\
<3 \\
<3\end{array}$} & \multirow{2}{*}{$\begin{array}{l}\text { PCR } \\
\text { analysis } \\
* a\end{array}$} \\
\hline & $\begin{array}{l}\text { Wet food } \\
\text { (packed) }\end{array}$ & Cat food & & & \\
\hline 2 & $\begin{array}{l}\text { Dry food } \\
\text { (repacked) }\end{array}$ & Dog food & $\begin{array}{l}2.1 \\
2.2\end{array}$ & $\begin{array}{l}<3 \\
<3\end{array}$ & $-{ }^{b}$ \\
\hline 3 & $\begin{array}{l}\text { Wet food } \\
\text { (packed) }\end{array}$ & Dog food & $\begin{array}{l}3.1 \\
3.2\end{array}$ & $\begin{array}{l}<3 \\
<3\end{array}$ & - \\
\hline 4 & $\begin{array}{l}\text { Wet food } \\
\text { (packed) }\end{array}$ & Cat food & $\begin{array}{l}4.1 \\
4.2\end{array}$ & $\begin{array}{l}<3 \\
<3\end{array}$ & * \\
\hline 5 & $\begin{array}{l}\text { Wet food } \\
\text { (packed) }\end{array}$ & Cat food & $\begin{array}{l}5.1 \\
5.2\end{array}$ & $\begin{array}{l}<3 \\
<3\end{array}$ & - \\
\hline 6 & $\begin{array}{l}\text { Dry food } \\
\text { (packed) }\end{array}$ & Cat food & $\begin{array}{l}6.1 \\
6.2\end{array}$ & $\begin{array}{l}<3 \\
<3\end{array}$ & - \\
\hline 7 & $\begin{array}{l}\text { Treat } \\
\quad \text { (unpacked) }\end{array}$ & Dog treat & $\begin{array}{l}7.1 \\
7.2\end{array}$ & $\begin{array}{l}<3 \\
<3\end{array}$ & - \\
\hline 8 & $\begin{array}{l}\text { Wet food } \\
\text { (packed) }\end{array}$ & Dog food & $\begin{array}{l}8.1 \\
8.2\end{array}$ & $\begin{array}{l}<3 \\
<3\end{array}$ & * \\
\hline 9 & $\begin{array}{l}\text { Wet food } \\
\text { (canned) }\end{array}$ & Dog food & $\begin{array}{l}9.1 \\
9.2\end{array}$ & $\begin{array}{l}<3 \\
<3\end{array}$ & - \\
\hline 10 & $\begin{array}{l}\text { Wet food } \\
\text { (packed) }\end{array}$ & Cat food & $\begin{array}{l}10.1 \\
10.2\end{array}$ & $\begin{array}{l}<3 \\
<3\end{array}$ & * \\
\hline 11 & $\begin{array}{l}\text { Dry food } \\
\text { (packed) }\end{array}$ & Cat food & $\begin{array}{l}11.1 \\
11.2\end{array}$ & $\begin{array}{l}<3 \\
<3\end{array}$ & - \\
\hline 12 & $\begin{array}{l}\text { Wet food } \\
\text { (canned) }\end{array}$ & Cat food & $\begin{array}{l}12.1 \\
12.2\end{array}$ & $\begin{array}{l}<3 \\
<3\end{array}$ & - \\
\hline 13 & $\begin{array}{l}\text { Dry food } \\
\quad \text { (repacked) }\end{array}$ & Dog food & $\begin{array}{l}13.1 \\
13.2\end{array}$ & $\begin{array}{l}<3 \\
<3\end{array}$ & - \\
\hline 14 & $\begin{array}{l}\text { Treat } \\
\quad \text { (unpacked) }\end{array}$ & Dog treat & $\begin{array}{l}14.1 \\
14.2\end{array}$ & $\begin{array}{l}<3 \\
<3\end{array}$ & - \\
\hline 15 & $\begin{array}{l}\text { Treat } \\
\quad \text { (unpacked) }\end{array}$ & Dog treat & $\begin{array}{l}15.1 \\
15.2\end{array}$ & $\begin{array}{l}<3 \\
<3\end{array}$ & - \\
\hline 16 & $\begin{array}{l}\text { Treat } \\
\quad \text { (unpacked) }\end{array}$ & Dog treat & $\begin{array}{l}16.1 \\
16.2\end{array}$ & $\begin{array}{l}<3 \\
<3\end{array}$ & - \\
\hline 17 & $\begin{array}{l}\text { Treat } \\
\quad \text { (unpacked) }\end{array}$ & Dog treat & $\begin{array}{l}17.1 \\
17.2\end{array}$ & $\begin{array}{l}<3 \\
<3\end{array}$ & - \\
\hline 18 & $\begin{array}{l}\text { Dry food } \\
\quad \text { (repacked) }\end{array}$ & Dog food & $\begin{array}{l}18.1 \\
18.2\end{array}$ & $\begin{array}{l}<3 \\
<3\end{array}$ & - \\
\hline 19 & $\begin{array}{l}\text { Dry food } \\
\quad \text { (repacked) }\end{array}$ & Dog food & $\begin{array}{l}19.1 \\
19.2\end{array}$ & $\begin{array}{l}<3 \\
<3\end{array}$ & - \\
\hline 20 & $\begin{array}{l}\text { Dry food } \\
\text { (repacked) }\end{array}$ & Cat food & $\begin{array}{l}20.1 \\
20.2\end{array}$ & $\begin{array}{l}<3 \\
<3\end{array}$ & - \\
\hline 21 & $\begin{array}{l}\text { Treat } \\
\text { (packed) }\end{array}$ & Dog treat & $\begin{array}{l}21.1 \\
21.2\end{array}$ & $\begin{array}{l}<3 \\
<3\end{array}$ & - \\
\hline 22 & $\begin{array}{l}\text { Treat } \\
\quad \text { (repacked) }\end{array}$ & Dog treat & $\begin{array}{l}22.1 \\
22.2\end{array}$ & $\begin{array}{l}<3 \\
<3\end{array}$ & - \\
\hline 23 & $\begin{array}{l}\text { Dry food } \\
\quad \text { (repacked) }\end{array}$ & Cat food & $\begin{array}{l}23.1 \\
23.2\end{array}$ & $\begin{array}{l}<3 \\
<3\end{array}$ & - \\
\hline 24 & $\begin{array}{l}\text { Treat } \\
\quad \text { (repacked) }\end{array}$ & Dog treat & $\begin{array}{l}24.1 \\
24.2\end{array}$ & $\begin{array}{l}<3 \\
<3\end{array}$ & - \\
\hline 25 & $\begin{array}{l}\text { Household } \\
\text { leftover }\end{array}$ & Dog food & $\begin{array}{l}25.1 \\
25.2\end{array}$ & $\begin{array}{l}23 \\
9.2\end{array}$ & - \\
\hline 26 & $\begin{array}{l}\text { Household } \\
\text { leftover }\end{array}$ & Dog food & $\begin{array}{l}26.1 \\
26.2\end{array}$ & $\begin{array}{l}>1100 \\
>1100\end{array}$ & - \\
\hline 27 & $\begin{array}{l}\text { Household } \\
\text { leftover }\end{array}$ & Dog food & $\begin{array}{l}27.1 \\
27.2\end{array}$ & $\begin{array}{l}460 \\
240\end{array}$ & - \\
\hline 28 & $\begin{array}{l}\text { Household } \\
\text { leftover }\end{array}$ & Cat food & $\begin{array}{l}28.1 \\
28.2\end{array}$ & $\begin{array}{l}<3 \\
<3\end{array}$ & - \\
\hline
\end{tabular}


Table 1 continued

\begin{tabular}{lccccc}
\hline $\begin{array}{l}\text { Sample } \\
\text { numbers }\end{array}$ & \multicolumn{2}{l}{ Types of samples } & Replicates & MPN/g & $\begin{array}{l}\text { PCR } \\
\text { analysis }\end{array}$ \\
\hline 29 & $\begin{array}{l}\text { Household } \\
\text { leftover }\end{array}$ & Dog food & 29.1 & $<3$ & - \\
& & 29.2 & $<3$ & \\
30 & Household & Dog food & 30.1 & $<3$ & - \\
& leftover & & 30.2 & $<3$ & \\
31 & Household & Cat food & 31.1 & $<3$ & - \\
& leftover & & 31.2 & $<3$ & \\
32 & Household & Cat food & 32.1 & $<3$ & - \\
& leftover & & 32.2 & $<3$ & \\
\hline
\end{tabular}

a Symbol $\left(^{*}\right)$ indicates PCR analysis was not performed due to unavailability of primers

b Symbol $( \pm)$ indicates positive and negative result of the presence of $L$. monocytogenes

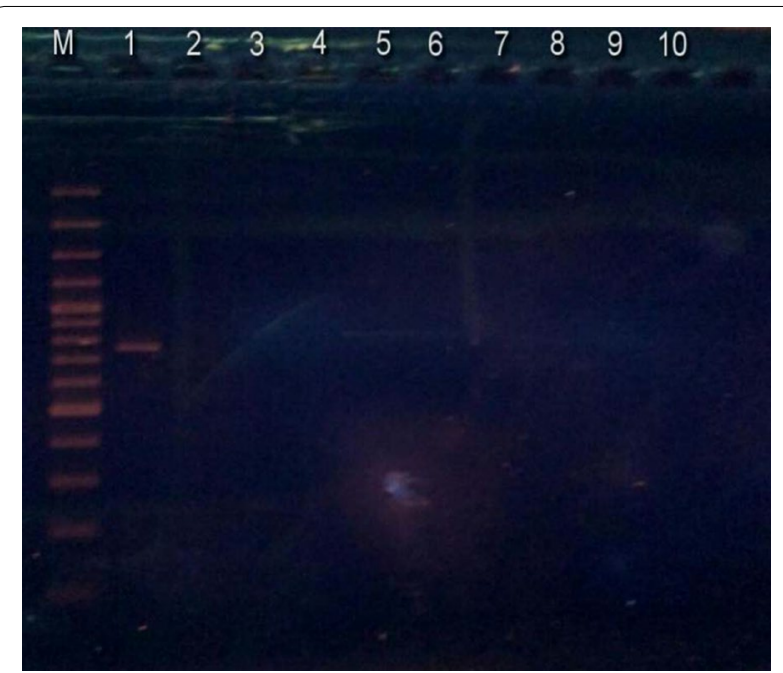

Fig. 1 Representative gel image of PCR amplification. Lanes M, DNA ladder (100 bp); lanes 1, positive control (730 bp); lanes 2-10, sample 24 to sample 32

Table 2 Quantity of Listeria species in pet food samples examined using MPN method

\begin{tabular}{llll}
\hline Types of pet food & \multicolumn{3}{l}{ MPN/g value } \\
\cline { 2 - 4 } & Minimum & Median & Maximum \\
\hline Wet pet food & $<3$ & $<3$ & $<3$ \\
Dry pet food & $<3$ & $<3$ & $<3$ \\
Treats & $<3$ & $<3$ & $<3$ \\
Human leftover food & $<3$ & $<3$ & $>1100$ \\
\hline
\end{tabular}

\section{Discussion}

In order to enumerate and detect Listeria monocytogenes in dog/cat food, a PCR-based method was combined with MPN method. The application of PCR, a molecular method, can help to overcome false-negative results that occur as a result of insufficient recovery during the enrichment procedures. When compared to the traditional method whereby MPN is coupled with a biochemical test, MPN-PCR has reduced the identification and enumeration process from about 10 days to 2 days. As a result, the combination of these two methods (MPN and PCR) has proved to be simpler, more reliable, and less laborious. In addition, MPN is generally preferred when the level of L. monocytogenes in the sample is expected to be low, i.e., $\leq 10-100 \mathrm{MPN} / \mathrm{g}$ [10]. This was further proved by a study conducted by Chen et al. [4] as the MPN method was observed to be more precise than direct plating for most of the samples where the levels of $L$. monocytogenes were low. Since most of the samples examined in this study are commercially prepared pet food samples or cooked in the case of the human leftover food, it is possible for these samples to have low levels of L. monocytogenes in a case of contamination.

If only direct PCR was to be performed on the cat/ dog food samples, it is possible for false positive results to occur due to the presence of dead cells. The incorporation of MPN method which allows only viable cells to grow can solve this problem by complementing the PCR method for accurate detection of L. monocytogenes [22]. The primers used in this study amplified a specific region present in the hly gene of L. monocytogenes. These primers are highly specific toward Listeria monocytogenes and do not amplify any DNA sequence present in other Listeria spp. or other non-Listeria organisms [1].

Microorganisms in foods are often injured and become sensitive to the selective agents present in the media recommended for their isolation. As a result, in order to overcome this limitation, the recovery of stressed cells is achieved by a pre-enrichment step in a non-selective broth which is prior to the selective enrichment [15]. Buffered peptone water was used in the pre-enrichment step of this study. Fraser broth was then used as a diagnostic enrichment broth. The modification of USDA secondary enrichment broth through the addition of lithium chloride and ferric ammonium citrate led to the production of a new enrichment broth called Fraser broth. Fraser broth contains esculin, and since all Listeria spp. are capable of hydrolyzing esculin, the broth will turn black in the presence of Listeria species. Cultures which do not turn black can be considered free of Listeria spp., and further analysis may be unnecessary. However, potential negative results with Fraser broth can occur and as a result, it is advised to plate all cultures for further analysis $[6,13]$. In this study, the result shown in Fraser broth was further confirmed using PCR.

In Malaysia, cases of listeriosis have not been reported and this can be due to the omission of the L. monocytogenes among the reported pathogens. However, studies 
have reported that L. monocytogenes has been isolated from various types of food such as fish, chicken, beef, and poultry $[3,10]$. When it comes to cat and dog food, there are a very limited data with regard to the contamination of these pet food diets by L. monocytogenes around the world. In Malaysia, there is no data regarding the contamination of dog or cat food diets with any type of microorganism. Studies conducted by Nemser et al. [18] and US Food and Drug Administration [5] are one of the few studies that reported the contamination of commercially prepared dog and cat food diets by L. monocytogenes. However, the contaminated dog and cat food diets were found to be commercially prepared raw foods. To the best of our knowledge, there is no commercially prepared raw pet food for cats and dogs in Malaysia. Hence, the types of dog and cat food diets examined were commercially prepared dry pet food (Kibbles), wet pet food, and treats. Furthermore, commercially prepared raw dog and cat food diets were replaced by human leftover foods that are given to companion animals (dogs and cats). The result obtained showed that $L$. monocytogenes were not present in any of the samples. This indicates that none of the samples even the unpacked treats that were displayed in shops without proper packaging or the repacked pet food were contaminated by $L$. monocytogenes.

Water activity $\left(\mathrm{a}_{\mathrm{w}}\right)$ is a practical tool in the development and production of safe and stable pet food diets since it is critical for microbial growth. The optimum water activity for the growth of L. monocytogenes is $\geq 0.97$; however, this bacterium has been observed to multiply at $a_{w}$ values as low as 0.90 [11]. Dog and cat food diets have different water activity, and this can be due to the usage of different raw materials or extrusion techniques (in a case of dry pet food) [2]. According to Timmons (2006 as cited in 2), the water activity for dry pet food and hard treats ranges from 0.40 to 0.45 , whereas for soft pet foods the water activity falls between 0.60 and 0.85 . However, according to Oni et al. [19], the water activity of different dry dog food diets was observed to be in the range of $0.495-0.653$. Furthermore, the water activity of canned food is higher than 0.85 , and as a result, the canned foods are acidified (Timmons, 2006 as cited in 2). This shows that the water activity of these commercially prepared dog and cat food diets is not suitable for the growth of $L$. monocytogenes. As a result, the low water activity of the dry pet food and treats as well as the acidity of the wet pet food diets can be one of the reasons that led to the absence of L. monocytogenes in the commercial dog and cat food diets. However, it is important to note that, in a case of contamination, L. monocytogenes will still be alive at low water activity value and they can start to multiply once they find a suitable environment $[2,11]$.
Moreover, 37.5\% (three samples) of the household samples showed turbidity in the Fraser broth, indicating the presumptive presence of $L$. monocytogenes. However, when PCR was performed for these samples, L. monocytogenes was not detected. The leftover household samples were all cooked food prepared for human consumption. After the families finished eating, they immediately gave the leftover food to the pets and in the case of two samples (sample 25 and 26); the food was stored for the next day. They left the food outside without proper refrigeration until the next day, and they gave it to their pets as breakfast. When processed in the laboratory, these two samples showed the presence of Listeria. Even though L. monocytogenes is the primary human pathogen, there have been rare cases of illness caused by $L$. innocua, $L$. ivanovii, and $L$. seeligeri [8]. Hence, there are chances that these samples $(25,26$, and 27$)$ might have been contaminated with these species but not $L$. monocytogenes. Contamination by Listeria spp. might have been due to cross-contamination after cooking or contamination of the ingredients used to prepare the food provided that the food was not cooked properly.

These dog and cat food samples may be free from $L$. monocytogenes making them safe for consumption by dogs and cats. However, there are chances that these pet food diets may have been contaminated by other pathogens such as Salmonella and Escherichia coli [18]. As a result, it is essential for the pet owners to be careful when handling pet food. Risk mitigation practices and proper pet food handling can be effective in reducing the exposure risk. It is highly recommended to wash hands after touching pet food, avoid cross-contamination between human food and pet food, and avoid the ingestion of pet food by infants and children [12]. In addition, when feeding a pet wet food from cans and pouches, immediately cover and refrigerate any of the food that is left in the container and any wet food that the pet did not eat during the meal should be thrown away. Dry pet food (in its original bag) should be stored in a clean plastic container with a lid, and the top of the bag should be folded or closed [7].

\section{Conclusion}

To conclude, Listeria monocytogenes was not present in any of the pet food samples examined. However, contamination of these pet food diets by other microorganisms is possible. Therefore, future studies on the contamination of pet food diets by other microorganisms such as Salmonella are highly encouraged. Even though none of the samples were positive for L. monocytogenes, pet owners are advised to employ risk mitigation practices such as washing of hands after touching pet food. In Malaysia, this study is the first biosafety assessment of $L$. 
monocytogenes in dog and cat food. Hence, its findings can contribute to the building of a database for knowledge development.

\author{
Abbreviations \\ L. monocytogenes: Listeria monocytogenes; MPN: most probable number; PCR: \\ polymerase chain reaction; BPW: buffered peptone water; AGE: agarose gel \\ electrophoresis; TBE: tris/borate/EDTA; FDA: Food and Drug Administration.
}

\section{Authors' contributions}

LMB conceived the study and was involved in the design and coordination of study and manuscript drafting. VU was involved in the manuscript drafting and editing. FMT was involved in the sampling collection, processing and data analysis. KA was involved in the final editing of the manuscript. All authors read and approved the final manuscript.

\section{Acknowledgements}

This study was partially funded by Tun Openg Chair (Research Grant Scheme), F07(ORC)/1223/2015/(04). The authors appreciate the assistance given by laboratory assistants, postgraduates, and undergraduates from the Department of Molecular Biology in the Faculty of Resource Science and Technology, Universiti Malaysia Sarawak.

\section{Competing interests}

The authors declare that they have no competing interests.

\section{Availability of supporting data}

The data generated and analyzed in this study are available to readers as in the manuscript.

\section{Consent for publication}

Not applicable.

\section{Ethics approval and consent to participate}

Not applicable.

\section{Funding}

This project was partially funded by Tun Openg Chair (Research Grant Scheme), F07(ORC)/1223/2015/(04).

\section{Publisher's Note}

Springer Nature remains neutral with regard to jurisdictional claims in published maps and institutional affiliations.

Received: 15 January 2018 Accepted: 9 March 2018

Published online: 23 March 2018

\section{References}

1. Awaisheh SS. Survey of Listeria monocytogenes and other Listeria sp. contamination in different common ready-to-eat food products in Jordan. Pak J Biol Sci. 2009;12:1491-7.

2. Başer Ö, Yalçin S. Determination of some quality characteristics in pet foods. Vet J Ankara Univ. 2017;64:21-4.

3. Chapman MP. Listerellosis in a dog, a field case. N Am Vet. 1947;28:532-8.

4. Chen Y, Pouillot R, Burall LS, Strain EA, Van Doren JM, De Jesus AJ, Laasri A, Wang H, Ali L, Tatavarthy A, Zhang G, Hua L, Day J, Sheth I, Kang J, Sahu S, Srinivasan D, Browna EW, Parish M, Zink DL, Datta AR, Hammack TS, Macarisin D. Comparative evaluation of direct plating and most probable number for enumeration of low levels of Listeria monocytogenes in naturally contaminated ice cream products. Int J Food Microbiol. 2017;241:15-22.

5. Get the facts! Raw pet food diets can be dangerous to you and your pet. U.S Food and Drug Administration (FDA). https://www.fda.gov/ animalveterinary/resourcesforyou/animalhealthliteracy/ucm373757.htm (2017). Accessed 2 May 2017.

6. Gorski L. Phenotypic identification. In: Liu D, editor. Handbook of Listeria monocytogenes. Boca Raton: CRC Press; 2008. p. 139-68.

7. Imanishi M, Rotstein DS, Reimschuessel R, Schwensohn CA, Woody DH $J$ r, Davis SW, Hunt AD, Arends KD, Achen M, Cui J, Zhang Y, Denny LF, Phan QN, Joseph LA, Tuite CC, Tataryn JR, Behravesh CB. Outbreak of Salmonella enterica serotype Infantis infection in humans linked to dry dog food in the United States and Canada, 2012. J Am Vet Med Assoc. 2014;244:545-53

8. Jeyaletchumi P, Tunung R, Margaret SP, Radu S, Farinazleen MG, Cheah YK. Detection of Listeria monocytogenes in foods. Int Food Res $\mathrm{J}$. 2010;17:1-11.

9. Jeyaletchumi P, Tunung R, Margaret SP, Radu S, Ghazali FM, Cheah YK, Nishibuchi M, Nakaguchi Y, Malakar PK. Quantification of Listeria monocytogenes in salad vegetables by MPN-PCR. Int Food Res J. 2010;17:281-6.

10. Kuan CH, Goh SG, Loo YY, Chang WS, Lye YL, Puspanadan S, Tang JYH, Nakaguchi Y, Nishibuchi M, Mahyudin NA, Radu S. Prevalence and quantification of Listeria monocytogenes in chicken offal at the retail level in Malaysia. Poult Sci. 2013;92:1664-9.

11. Lado BH, Yousef AE. Characteristics of Listeria monocytogenes important to food processors. In: Ryser ET, Marth EH, editors. Listeria, listeriosis and food safety. Boca Raton: CRC Press; 2007. p. 157-214.

12. Lambertini E, Buchanan RL, Narrod C, Ford RM, Baker RC, Pradhan AK Quantitative assessment of human and pet exposure to Salmonella associated with dry pet foods. Int J Food Microbiol. 2016;216:79-90.

13. Law JWF, Ab Mutalib NS, Chan KG, Lee LH. An insight into the isolation, enumeration, and molecular detection of Listeria monocytogenes in food. Front Microbiol. 2015:6:1-15.

14. Loncarevic S, Artursson K, Johansson I. A case of canine cutaneous listeriosis. Vet Dermatol. 1999;10:69-71.

15. Magalhães R, Mena C, Ferreira V, Almeida G, Silva J, Teixeira P. Traditional methods for isolation of Listeria monocytogenes. In: Jordan K, Fox EM, Wagner M, editors. Listeria monocytogenes: methods and protocols. New York: Springer; 2014. p. 15-30.

16. Marian MN, Aminah SS, Zuraini MI, Radu S, Maimunah M, Lee HY, Wong WC, Nillian E. MPN-PCR detection and antimicrobial resistance of Listeria monocytogenes isolated from raw and ready-to-eat foods in Malaysia. Food Control. 2012;28:309-14.

17. Marien M, Decostere A, Werbrouck H, Van Coillie E, Paepe D, Moyaert H, Pasmans F, Daminet S, Haesebrouck F. Isolation of Listeria monocytogenes from the gallbladder of a dog with liver insufficiency. Vlaams Diergeneeskundig Tijdschrift. 2007;76:352-4.

18. Nemser SM, Doran T, Grabenstein M, McConnell T, McGrath T, Pamboukian R, Smith AC, Achen M, Danzeisen G, Kim S, Liu Y, Robeson S, Rosario G, Wilson KM, Reimschuessel R. Investigation of Listeria, Salmonella, and toxigenic Escherichia coli in various pet foods. Foodborne Pathogens Dis. 2014;11:706-9.

19. Oni RA, Lambertin E, Buchanan RL. Assessing the potential for Salmonella growth in rehydrated dry dog food. Int J Food Contam. 2016;3:20.

20. Palerme J-S, Po CP, Parsons CT, Kathariou S, Ward TJ, Jacob ME. Isolation and characterization of atypical Listeria monocytogenes associated with a canine urinary tract infection. J Vet Diagn Invest. 2016;28:604-7.

21. Pritchard JC, Jacob ME, Ward TJ, Parsons CT, Kathariou S, Wood MW. Listeria monocytogenes septicemia in an immunocompromised dog. Vet Clin Pathol. 2016;45:254-9.

22. Pui CF, Wong WC, Chai LC, Nillian E, Ghazali FM, Cheah YK, Nakaguchi Y, Nishibuchi M, Radu S. Simultaneous detection of Salmonella spp., Salmonella typhi and Salmonella typhimurium in sliced fruits using multiplex PCR. Food Control. 2011;22:337-42.

23. Recalls \& withdrawals. U.S Food and Drug Administration (FDA). http:// www.fda.gov/AnimalVeterinary/SafetyHealth/RecallsWithdrawals/default. htm (2017). Accessed 11 May 2017.

24. Schroeder H, Van Rensburgv IBJ. Generalised Listeria monocytogenes infection in a dog. J S Afr Vet Assoc. 1993;64:133-6.

25. Sutton $\mathrm{S}$. The most probable number method and its uses in enumeration, qualification, and validation. J Valid Technol. 2010;16:35-8. 